\title{
Mass lesions of ovary - Tumor markers can be misleading
}

\author{
Moothiringode Chitrabhanu Savithri, Usha Mary Abraham \\ Department of Pathology, Amala Institute of Medical Sciences, Amalanagar, Thrissur, Kerala, India
}

\section{A B S T R A C T}

Background: Ovarian mass lesions could be neoplastic or non neoplastic. The less aggressive lesions should be distinguished from carcinomas which require extensive surgical procedures. CA-125 is a tumor marker used for evaluating ovarian carcinomas. In this series we found seven cases of sex cord stromal tumors (SCT) and endometriotic cysts with raised CA-125 levels, the highest value being $1540 \mathrm{IU} / \mathrm{ml}$. Aims and Objectives: 1) To retrospectively evaluate cases which presented as mass lesions of ovary over a two year period along with CA-125 levels if available. 2) To find out the number of non carcinomatous lesions with elevation of the tumor marker CA-125. Materials and Methods: Total number of ovarian tumors and endometriotic cysts reported in the Department of Pathology, Amala Institute of Medical Sciences, Thrissur, Kerala, India in the two year period of 2012 and 2013 were retrospectively identified. CA-125 levels if available were noted. Results: Primary ovarian tumors comprised 180 cases, the rest being metastastic adenocarcinomas. There were 15 cases of SCT and 21 endometriotic cysts. CA 125 levels were increased in 2 cases each of granulosa cell tumors and fibrothecomas and 3 cases of endometriotic cysts. Highest value was $1540 \mathrm{lU} / \mathrm{ml}$. Conclusion: Elevation of the tumor marker CA 125 often tricks the clinician into making a provisional diagnosis of carcinoma of ovary. It is important to understand the limitations in the interpretation of tumor markers so that more aggressive treatment modalities are avoided.

Key words: Sex cord stromal tumors, Endometriosis, Tumor markers, CA-125
Access this article online Website:

http://nepjol.info/index.php/AJMS

DOI: 10.3126/ajms.v6i3.10983

\section{INTRODUCTION}

Ovarian mass lesions could be neoplastic or non neoplastic. Neoplastic lesions can be benign, malignant or potentially malignant. Neoplasms may be surface epithelial tumors, sex cord stromal tumors, germ cell tumors, other miscellaneous primary tumors and metastatic tumors. Sex cord stromal tumors (SCT) of the ovary are comparatively rare and occur in a wide age range. They are potentially malignant tumors and may be functional, resulting in menstrual irregularities, infertility and sometimes androgenic effects. They present as solid or cystic adenexal masses. Endometriosis of the uterine adenexa can also present as mass lesions. These lesions may need to be distinguished from the more aggressive carcinomas which require extensive surgical procedures.

Tumor markers are biomarkers found in the blood, urine or body tissues. CA-125 is a tumor marker used for evaluating ovarian carcinomas. Normal value is less than $35 \mathrm{IU} / \mathrm{ml}$. It has been found to be elevated significantly in ovarian surface epithelial malignancies. An elevated CA-125 level often makes the clinician to over diagnose a case as carcinoma even though there are many gynecologic and non gynecologic conditions associated with increased levels. Our objective in this study is to emphasize this point and to identify non carcinoma cases with significant elevations of CA-125 levels.

In this series there were 180 cases of primary ovarian tumors and 21 cases of endometriotic cysts. We found seven cases with raised CA-125 levels which included 4 cases of SCT and 3 cases of endometriotic cysts.

\section{MATERIALS AND METHODS}

Total number of ovarian tumors reported in the Department of Pathology, Amala Institute of Medical 
Sciences, Thrissur, Kerala, India in the two year period of 2012 and 2013 were retrospectively identified.

CA-125 values in these cases if available were analyzed. Endometriotic cysts biopsied during this period were also taken into account along with CA-125 values if available.

\section{RESULTS}

Primary ovarian tumors comprised 180 cases, the rest being metastastic adenocarcinomas. 144 cases were surface epithelial tumors, 15 were SCT and 17 were germ cell tumors. CA-125 levels were available in 67 cases.

The commonest tumors were serous tumors -95 cases- belonging to different subcategories (Table 1). One case each of benign and borderline mucinous tumors showed minimal elevations of CA-125 values, 49 and $51.6 \mathrm{IU} / \mathrm{ml}$.

Among the SCT there were granulosa cell tumors, thecomas, fibrothecomas and sclerosing stromal tumor of ovary, (Table 2).

Germ cell tumors comprised 17 cases. None showed elevated CA-125 values (Table 3). Metastatic carcinoma and NHL completed the list. Among the 21 cases of endometriotic cysts diagnosed during this period 4 cases had CA-125 levels done preoperatively and 3 cases showed increased levels (Table 4).

CA 125 levels were increased in 2 cases of granulosa cell tumor- $48 \mathrm{IU} / \mathrm{ml}$ and $86.15 \mathrm{IU} / \mathrm{ml}$. The two cases of

\begin{tabular}{lccc}
\hline \multicolumn{4}{l}{ Table 1: Surface epithelial tumors } \\
\hline Types of tumor & $\begin{array}{l}\text { No of } \\
\text { cases }\end{array}$ & $\begin{array}{c}\text { Cases with } \\
\text { CA-125 values }\end{array}$ & $\begin{array}{c}\text { Levels } \\
\text { increased in }\end{array}$ \\
\hline Benign serous tumors & 45 & 11 & 1 \\
Borderline serous tumors & 7 & 3 & 2 \\
Serous carcinoma & 42 & 22 & 19 \\
Benign mucinous tumors & 25 & 7 & 1 \\
Borderline mucinous tumors & 8 & 2 & 1 \\
Mucinous carcinoma & 7 & 2 & Nil \\
Endometrioid carcinoma & 3 & 1 & Nil \\
Clear cell adenofibroma & 4 & 2 & 1 \\
and carcinoma & & & \\
Transitional cell carcinoma & 2 & 2 & 1 \\
\hline
\end{tabular}

\begin{tabular}{lccc}
\multicolumn{4}{l}{ Table 2: Sex cord stromal tumors } \\
\hline Types of tumor & $\begin{array}{c}\text { No of } \\
\text { cases }\end{array}$ & $\begin{array}{c}\text { Cases with } \\
\text { CA-125 values }\end{array}$ & $\begin{array}{c}\text { Levels } \\
\text { increased in }\end{array}$ \\
\hline Granulosa cell tumors & 7 & 4 & $2^{*}$ \\
Fibrothecomas & 4 & 3 & $2^{* *}$ \\
Thecomas & 3 & 1 & 0 \\
Sclerosing stromal tumors & 1 & 1 & 0 \\
\hline${ }^{*} 8 \mathrm{IU} / \mathrm{ml}$ and $86.15 \mathrm{IU} / \mathrm{ml},{ }^{* *} 713 \mathrm{IU} / \mathrm{ml}$ and $1540 \mathrm{IU} / \mathrm{ml}$ &
\end{tabular}

fibrothecomas had values of $713 \mathrm{IU} / \mathrm{ml}$ and $1540 \mathrm{IU} / \mathrm{ml}$. Both cases had undergone torsion with free fluid in the abdominal cavity. The values were high in the 3 cases of endometriosis with the highest being $1450 \mathrm{IU} / \mathrm{ml}$. The latter case was associated with pancreatic cyst and elevated CA-19-9.

Among the seven cases of granulosa cell tumors all were perimenopausal. One patient showed simple hyperplasia of endometrium indicating estrogenic effect. Two cases of thecomas showed endometrial changes. One case showed disordered proliferation of endometrium and the other, endometrial adenocarcinoma in a background of hyperplasia. The one case of sclerosing stromal tumor had concurrent hypothyroidism.

\section{DISCUSSION}

The SCT of ovary arise from the ovarian stroma which is derived from sex cords of embryonic gonad. ${ }^{1}$ Sex cord stromal tumors of the ovary occur over a wide age range, with individual tumors occurring in different age groups. Because patients are often young and most tumors are unilateral, accurate diagnosis is necessary for proper treatment and maintenance of fertility, where desirable.

Accuracy of terminology is important. It is not enough that pathologists knowledgeable in the field know the meaning of the terms used. The name of the tumor or condition should reflect its biological behavior as accurately as possible because clinicians may be influenced in their choice of therapy by the terminology used and lay people may not readily grasp the implications of the diagnosis. $^{2}$

SCTs are relatively infrequent and accounts for about $7 \%$ of all primary ovarian tumors. ${ }^{3}$ In our series they form $8.1 \%$ of the total. They comprised granulosa cell tumors, thecomas,

\begin{tabular}{lccc}
\multicolumn{4}{l}{ Table 3: Germ cell tumors } \\
\hline Types of tumor & $\begin{array}{c}\text { No of } \\
\text { cases }\end{array}$ & $\begin{array}{c}\text { Cases with } \\
\text { CA-125 values }\end{array}$ & $\begin{array}{c}\text { Levels } \\
\text { increased in }\end{array}$ \\
\hline Benign cystic teratoma & 13 & 1 & 0 \\
Immature teratoma & 3 & 1 & 0 \\
Mixed germ cell tumors & 1 & 0 & 0 \\
\hline
\end{tabular}

\begin{tabular}{lccc} 
Table 4: Others & & & \\
\hline $\begin{array}{l}\text { Types of tumorl } \\
\text { lesion }\end{array}$ & $\begin{array}{c}\text { No of } \\
\text { cases }\end{array}$ & $\begin{array}{c}\text { Cases with } \\
\text { CA-125 values }\end{array}$ & $\begin{array}{c}\text { Levels } \\
\text { increased in }\end{array}$ \\
\hline $\mathrm{NHL}$ & 2 & 0 & 0 \\
Metastatic carcinoma & 5 & 2 & 1 \\
Endometriotic cysts & 21 & 4 & $3^{*}$ \\
\hline${ }^{*} 160 \mathrm{IU} / \mathrm{ml}, 917 \mathrm{IU} / \mathrm{ml}, 1450 \mathrm{IU} / \mathrm{ml}$ & &
\end{tabular}


fibrothecomas and a case of sclerosing stromal tumor. The endometrial changes observed which could be attributed to the functional tumors were simple hyperplasia, endometrial carcinoma in a background of hyperplasia and one case of endometrial polyp. Only 4 cases $(26.6 \%)$ showed evidence of hormonal activity. In a 20 year retrospective study by Haroon et al there were 480 cases of SCT of which 29 showed endometrial changes. ${ }^{3}$

Early detection is important in the treatment and prognosis of ovarian cancers. Use of serum markers for early detection has largely focused on CA-125 a high molecular weight mucin that was initially detected with a homologous double determinant radio immunoassay. ${ }^{4}$

Ca-125 is expressed in celomic epithelium during embryonic development. ${ }^{5}$ It is not expressed by normal adult or fetal ovary. It has been detected in fetal Mullerian duct derivatives as well as fetal serosal surface epithelia including pleura, peritoneum and pericardium. In adult tissues traces have been detected in fallopian tube, endometrium and endocervix. There have been many studies relating to the sensitivity and specificity of CA-125. Niloff et al in 1984 found no single gynecological disease to be associated with CA-125 levels exceeding $65 \mathrm{IU} / \mathrm{ml}$ and that a minority of pregnant women in 1st trimester had increased levels. ${ }^{6}$ Canney et al in 1984 found the sensitivity of CA-125 more than adequate extending to all histologic subtypes of epithelial neoplasms including mucinous subtype. ${ }^{5}$

Specificity of CA-125 is inadequate for screening particularly in premenopausal population in which endometriosis, adenomyosis and retrograde menstruation can produce elevations of antigen levels. ${ }^{4}$ However it is extremely useful in the follow up of surface epithelial malignancies.

Many reports are there in literature of increased levels of CA-125 in other types of ovarian tumors especially sex cord stromal tumors. There are also studies which reveal that CA-125 values were found elevated in cases of Non Hodgkin Lymphoma correlating with advanced disease and poor outcome. ${ }^{7}$ In our series CA-125 levels were not available in the 2 cases of NHL. Choi K et al in 2006 reported a case of granulosa cell tumor associated with Meigs'syndrome and elevated CA-125 levels of $82.49 \mathrm{IU} / \mathrm{ml}^{8}{ }^{8}$ There are reports of thecoma and fibrothecoma associated with Meigs syndrome and elevated CA-125 values upto $600 \mathrm{IU} / \mathrm{ml} .{ }^{9,10}$ Macci et al in 2014 reported an ovarian fibroma in association with Meigs' syndrome, hemolytic anemia and raised CA-125 values along with increased inflammatory markers -CRP and fibrinogen- where the clinical diagnosis was advanced ovarian cancer. In addition to the effusions, torsion with subsequent necrosis can result in elevated CA-125 levels. ${ }^{11}$ A case of twisted sclerosing stromal tumor also has been recently reported with Ca-125 levels of $339.20 \mathrm{IU} / \mathrm{ml} .{ }^{12}$

In the present series we had 4 SCTs with above normal Ca-125 values. The two granulosa cell tumors did not show any effusions and one case had only marginal elevation to $48 \mathrm{IU} / \mathrm{ml}$. The two fibrothecomas had undergone torsion and had free fluid in the abdomen. Both showed considerable elevation of CA-125; 713 and $1540 \mathrm{IU} / \mathrm{ml}$ respectively. Both were clinically diagnosed as malignancies. The 3 cases of endometriosis also were suspected to harbor tumor due to elevated levels of tumor markers.

\section{CONCLUSION}

Sex cord stromal tumors may be benign as in thecomas or potentially malignant as in the case of granulosa cell tumors. They are not aggressive like surface epithelial carcinomas. Endometriosis is a non neoplastic condition. We found seven cases belonging to these two categories with raised values of the tumor marker CA-125. This often tricks the clinician into making a provisional diagnosis of malignancy. It is important to understand the limitations in the interpretation of tumor marker levels so that more aggressive treatment modalities are avoided in such situations.

\section{REFERENCES}

1. Ellenson LH, Pirog EC. The Female Genital Tract. In: Kumar, Abbas, Fausto, Aster. Editors. Robbins and Cotran Pathologic Basis of Disease, $8^{\text {th }}$ ed. Elsevier; pp1005-1063.

2. Roth LM. Recent advances in the pathology and classification of ovarian sex cord stromal tumors. Int J Gynecol Pathol 2006;25:199-215.

3. Haroon S, Zia A, Idrees R, Memon A, Fatima $S$ and Kayani N. Clinicopathological spectrum of ovarian sex cord tumors; 20 years' retrospective study in a developing country. Journal of Ovarian Research 2013; 6:87.

4. Bast RC. Status of tumor markers in ovarian cancer screening. J Clin Oncol 2003; 21:200s-205s.

5. Canney PA, Moore M, Wilkinson PM and James RD. Ovarian cancer antigen CA 125: A prospective clinical assessment of its role as a tumor marker. Br J Cancer 1984;50:765-769.

6. Niloff JM, Knapp RC, Schaetzl E, Reynolds C and Bast RC. CA125 antigen level in obstetric and gynecologic patients. Obstet Gynecol 1984;64:703-707.

7. Zidan J, Hussein O, Basher W and Zohar S. Serum CA 125: A tumor marker for monitoring response to treatment and follow-up in patients with Non-Hodgkin's Lymphoma. The Oncologist 2004;9:417-21.

8. Choi K, Lee HJ, Pae JC, Oh SJ, Lim SY, Cho EY and Lee SS. Ovarian granulosa cell tumor presenting as Meigs' syndrome with elevated CA125. Korean J Intern Med 2006;20:105-109.

9. Vieira SC, Pimentel LHC, Ribeiro JCCB, Neto AFA and de 
Santana JOI. Meigs' syndrome with elevated CA 125: case report. Sao Paulo Med J 2003;121:210-212.

10. Yazdani S, Alijanpoor A, Sharbatdaran M, Bouzari Z, Abedisamakoosh M, Lakaieandi F, et al. Meigs' syndrome with elevated serum CA125 in a case of ovarian fibroma/thecoma. Caspian J Intern Med 2014;5(1):43-45.

11. Macci A, Maddedu C, Kotsonis P, Pietrangeli M and Paoletti AM.
Large twisted ovarian fibroma associated with Meigs' syndrome, abdominal pain and severe anemia treated by laparoscopic surgery. BMC Surgery 2014;14:38.

12. Junnare KK, Tajne $P$ and Naphade $P R$. A rare case of sclerosing stromal tumor of ovary with Meigs' syndrome presenting with torsion. Asian Journal of Medical Sciences 2014;5:116-118.

Authors Contribution:

MCS: Concept, Design, Definition and intellectual content, Literature search, Clinical search, Experimental search, Data acquisition, Data analysis, Manuscript preparation, Manuscript editing, Manuscript review, Guarantor; UMA: Definition and intellectual content, Literature search, Clinical search, Experimental search, Data acquisition, Data analysis.

Source of Support: Nil, Conflict of Interest: None declared. 